Original Research Paper

\title{
Compaction Properties of Silty Soils in Relation to Soil Texture, Moisture Content and Organic Matter
}

\author{
Prathuang Usaborisut and Jettapol Ampanmanee \\ Department of Agricultural Engineering, Faculty of Engineering at Kamphaengsaen, \\ Kasetsart University, Kamphaengsaen Campus, Nakhonpathom, Thailand
}

\author{
Article history \\ Received: 04-09-2015 \\ Revised: 06-10-2015 \\ Accepted: 26-12-2015 \\ Corresponding Author: \\ Prathuang Usaborisut \\ Department of Agricultural \\ Engineering, Faculty of \\ Engineering at \\ Kamphaengsaen, Kasetsart \\ University, Kamphaengsaen \\ Campus, Nakhonpathom, \\ Thailand \\ Email: fengptu@ku.ac.th
}

\begin{abstract}
Soil compaction is recognized as an increasingly challenging problem with regard to root growth and yield reduction in agricultural production in Thailand. The aim of this research was to study the effect of soil texture, moisture content and organic matter on the compaction properties of silty soils. Three soils with different silt contents were studied-loam, silty clay loam and silt loam. The study showed that compacting silt loam soil using the modified Proctor test resulted in a higher bulk density than from the oedometer test at $200 \mathrm{kPa}$. Statistical analysis showed that soil type and the moisture content significantly affected both the bulk density and penetration resistance. However, organic matter showed a significant effect only on the bulk density. The bulk density increased with increased moisture content. The bulk densities of compacted soils were higher in the order of loam, silt loam and silty clay loam. The penetration resistance seemed to increase with increased silt content. The differences in the bulk density and penetration resistance among these three soils decreased as the moisture content increased. Adding organic matter at $5 \%$ by weight to soils resulted in lower bulk densities of the soil using the oedometer test, with reductions of 3.9, 3.8 and $7.7 \%$ for loam, silty clay loam and silt loam, respectively. In order to avoid effects on root growth, it is recommended that machines with $200 \mathrm{kPa}$ of tire contact pressure should only work in fields with a moisture content not exceeding 20.27, 18.74 and $17.88 \%$ for loam, silt loam and silty clay loam, respectively.
\end{abstract}

Keywords: Soil Compaction, Silty Soil, Moisture Content, Organic Matter

\section{Introduction}

Soil compaction, mainly induced by the extensive use of heavy agricultural machinery, results in increases in the soil bulk density and soil strength. These properties determine the ease of root penetration, water availability and gaseous exchange in the soil; therefore, they have an important influence on plant growth and yield. Usaborisut and Niyamapa (2010) reported that the greatest reduction in the yield of sugarcane compared with a control field was $22.9 \%$, which resulted from compaction following 15 tractor passages. Usaborisut and Sukcharoenvipharat (2011) investigated compaction properties in sugarcane fields under mechanized farming and under manual labor farming. They found that the average value of soil bulk density samples under mechanized farming was $12.6 \%$ higher than and significantly different from farm practice under manual labor. In addition, the average value of the penetration resistance under mechanized farming was $23.3 \%$ higher than for manual labor. Yahya et al. (2009) conducted tests in an oil palm plantation field with a clay soil having about $50 \%$ clay, $30 \%$ silt and $20 \%$ sand and reported that with a treatment applying three trailer weights and four transportation frequencies, the results showed that the mean soil bulk density increased and the porosity decreased annually. However, the mean soil bulk density was still less than $1.0 \mathrm{~g} / \mathrm{cm}^{3}$. Tests on the root response to mechanization by Yahya et al. (2010) showed that the growth of oil palm roots was significantly affected by a 4 tonne trailer weight. Palms in compacted soil produced less primary and secondary roots but this 
was compensated for by the production of longer and thicker tertiary and quaternary roots. Al-Gaadi (2013) studied soil compaction under center pivot irrigation systems and their effect on crop performance. The results showed that the normalized difference vegetation index was inversely proportional to the soil compaction. Al-Gaadi (2012) stated that compaction can restrict and interfere with root growth, reduce the amount and size of soil pores, decrease soil infiltration, cause water-logging, reduce water infiltration and increases runoff and hence increase soil erosion. Sugarcane is one of the most important economic crops in Thailand. In 2013, about 100 million tonnes were produced from about 1.3 million hectares, which ranked Thailand fourth among world producers, after Brazil India and China (CAI, 2014). From 2002 to 2012 , there was a $27 \%$ increase in the sugarcane plantation area. Mechanized farming and poor management in farm practices can result in serious problems with soil compaction and in Thailand this is drawing the attention of both the government and private sector. The companies operating in the cane and sugar industry, have encouraged farmers to carry out subsoiling in sugarcane fields. Thai farmers are exposing new areas to sugarcane and sometimes these areas are unsuitable. Consequently, one of the most serious soil compaction issues is the compaction of silty soil which has special characteristics being too soft when wet but very strong when dry. Therefore, this research intended to clarify the effects of soil texture, moisture content and organic matter on the compaction properties of silty soil.

\section{Materials and Methods}

Sampling of silty soils was carried out in sugarcane fields where farmers claimed to have problems with the soil being very hard and too strong when the soil was dry but being very soft and slippery when wet. Sampling areas were located in Nakornpathom province in central Thailand. Soil samples were analyzed for soil texture classification (Table 1). The soils sampled were categorized as loam, silty clay loam and silt loam, with the percentage of silt varying from 40.72 to $55.44 \%$. The Atterberg limits are listed in Table 1.
In order to determine soil compaction to the maximum bulk density, two methods were used in the laboratory. One was the modified Proctor test method (ASTM D1557-12, 2012), which is used generally in civil engineering experiments for specifying the compaction characteristics of soil, but some researchers have also utilized this test in agricultural soil compaction studies (Carter, 1990; Da Silva et al., 1997). The other test used a standardized compaction treatment using an oedometer at a vertical, normal stress of $200 \mathrm{kPa}$ as $100 \%$ of degree of compactness (Hakansson and Lipiec, 2000). Soil penetration resistance was determined using a cone penetrometer having a conical tip with a $30^{\circ}$ angle of penetration. To determine the bulk density, soil cores were collected using cylinders with a height of $3 \mathrm{~cm}$ and a diameter of $5.55 \mathrm{~cm}$. The soil cores were oven-dried at $105^{\circ} \mathrm{C}$ and weighed to obtain the dry bulk density. The soil organic matter was measured using standard test methods (ASTM D2974-14, 2014). Thai-made sphagnum peat of medium grade that is traditionally used in the horticultural industry was added into the soil at $5 \%$ on a weight-to-weight basis in order to study its effect on compaction properties.

\section{Results}

\section{Maximum Bulk Densities by Different test methods}

Silt loam soil with $55.44 \%$ silt content was used in the test for maximum compaction. Under the modified Proctor test with a compacting power of $2,700 \mathrm{kN}$ $\mathrm{m} / \mathrm{m}^{3}$, the relationship between the bulk density and moisture content of the silt loam soil is shown in Fig. 1. The bulk density increased with increased moisture content and reached it maximum value at $1.92 \mathrm{~g} / \mathrm{cm}^{3}$ at a moisture content of $12 \%$. After that, when the moisture content was increased, the soil bulk density decreased. Similarly, under the oedometer test at a vertical, normal stress of $200 \mathrm{kPa}$, the bulk density increased with increased moisture content as shown in Fig. 1. The maximum value of bulk density was 1.65 $\mathrm{g} / \mathrm{cm}^{3}$ at $20 \%$ moisture content which was the highest moisture content it was possible to prepare. The maximum value derived from the modified Proctor test was $16.4 \%$ higher than for the oedometer test. Furthermore, the maximum value of the former was reached at a lower moisture content.

Table 1. Soil properties

\begin{tabular}{lllllll}
\hline & Soil classification & & & & \\
Soil texture & - & & Plastic & Liquid & Plastic \\
Sand (\%) & Silt (\%) & Clay (\%) & Limit (\%) & Limit (\%) & Index (\%) \\
\hline Silt loam & 25.24 & 55.44 & 19.32 & 17.22 & 27.07 & 9.85 \\
Silty clay loam & 17.68 & 50.72 & 31.60 & 17.95 & 23.33 & 5.38 \\
Loam & 41.96 & 40.72 & 17.32 & - & 18.78 & - \\
\hline
\end{tabular}




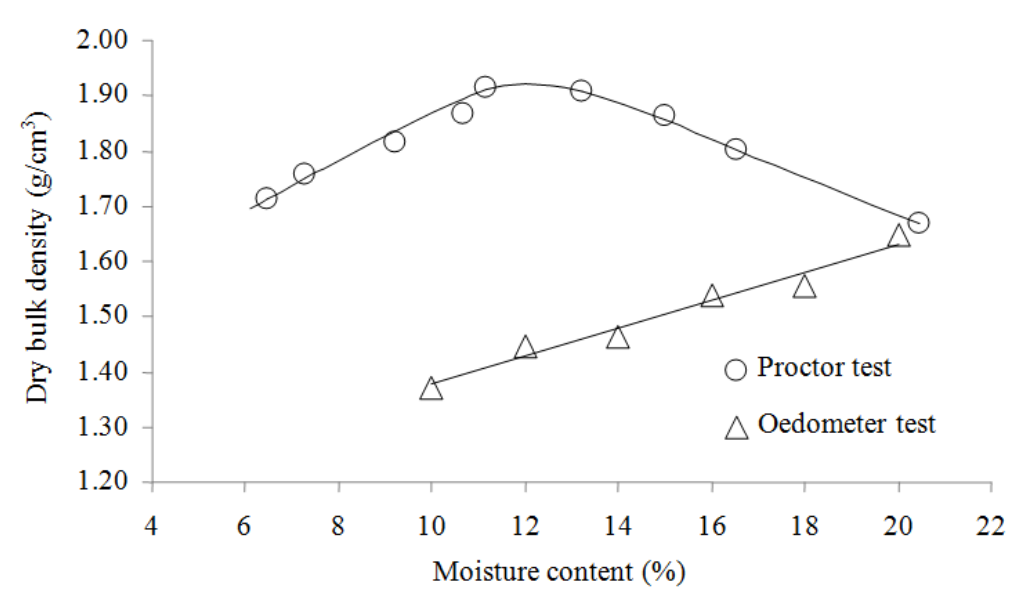

Fig. 1. Bulk density and moisture content using modified Proctor test and oedometer test

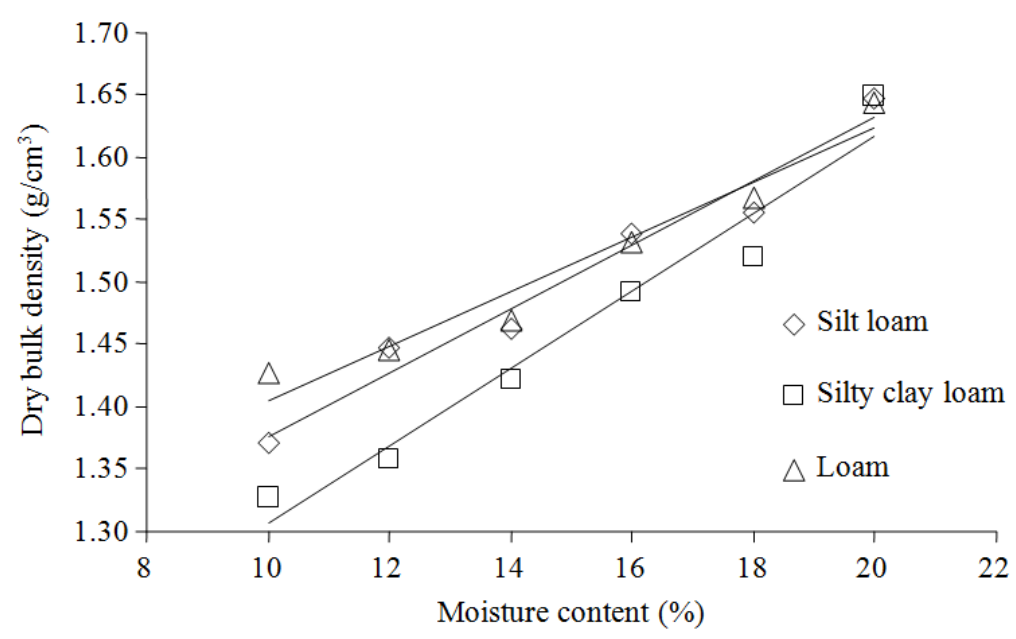

Fig. 2. Bulk density and moisture content for different soils

\section{Maximum Bulk Densities of Different Soils}

Loam, silty clay loam and silt loam which have different silt contents of $40.72,50.72$ and $55.44 \%$ respectively, as detailed in Table 1, were tested to determine the relationship between the bulk density and moisture content under a uni-axial compression of 200 $\mathrm{kPa}$. The bulk density increased with increased moisture content. The loam soil showed rather higher values of bulk density than the other two soils (Fig. 2). Moreover, the difference in the bulk density among these three soils seemed to decrease as the moisture content increased and at $20 \%$ moisture content they all had almost the same bulk density. It should be noted that soil samples could not be prepared that had a moisture content over $20 \%$.

\section{Soil Penetration Resistance of Different Soils}

Busscher et al. (1997) suggested that either a power or exponential equation was the most adequate for prediction of the penetration resistance as a function of the moisture content. The soil penetration resistance at the corresponding bulk density under a uni-axial compression of $200 \mathrm{kPa}$ can be expressed as an exponential relationship as shown in Fig. 3. The silty clay loam and silt loam both had a higher resistance than the loam soil especially at a low moisture content. When the moisture content increased, the penetration resistance decreased, with the silty clay loam and silt loam showing a greater decrease; consequently, they had nearly identical values at a moisture content of $20 \%$.

\section{Effect of Degree of Compactness}

The silt loam soil was used to test the effect of the degree of compactness. The oedometer tests were conducted at three levels of vertical, normal stresses- 150 (75\% degree of compactness), $170(85 \%)$ and 200 $(100 \%) \mathrm{kPa}$. Figure 4 shows that the bulk density was higher under higher uni-axial compression and the difference decreased as the moisture content increased. The average values of bulk density for all moisture 
contents were $1.50,1.44$ and $1.41 \mathrm{~g} / \mathrm{cm}^{3}$ for the oedometer tests at 200, 170 and $150 \mathrm{kPa}$, respectively. Fig. 5 shows the penetration resistance, with higher values under higher uni-axial compression, especially at a low moisture content, but a disordered pattern occurred over a range of high moisture content levels.

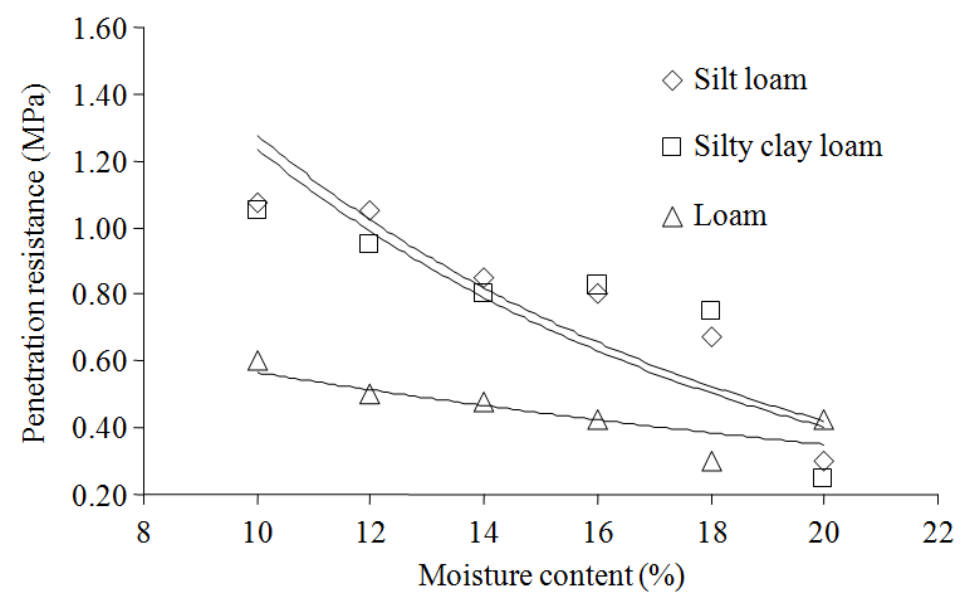

Fig. 3. Penetration resistance and moisture content for different soils

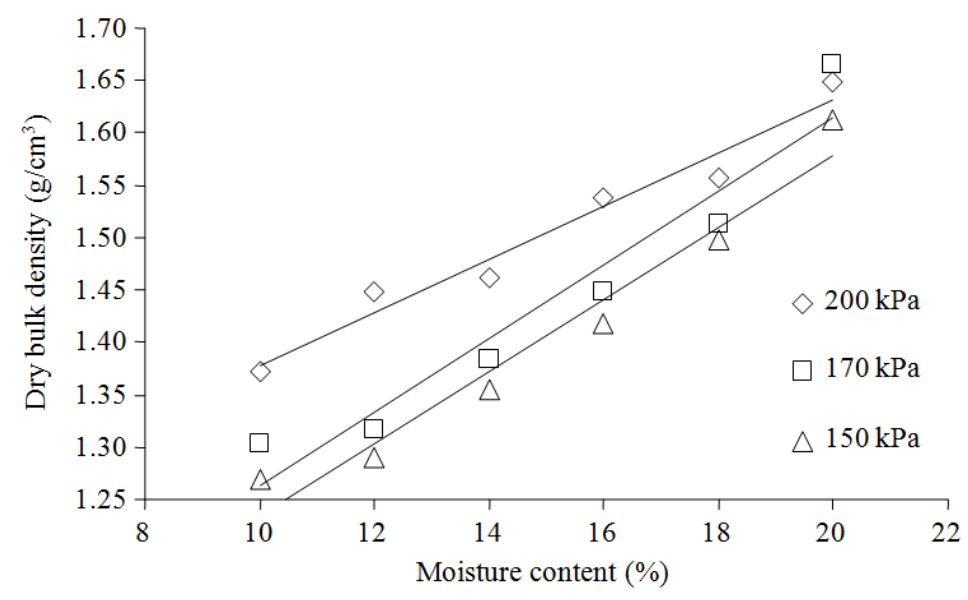

Fig. 4. Bulk density and moisture content under different compression stress

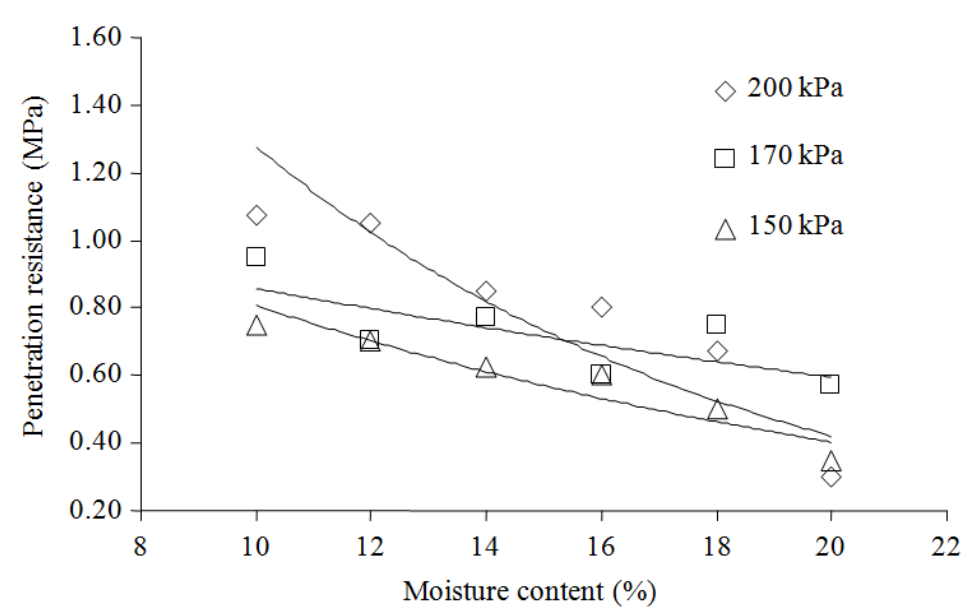

Fig. 5. Penetration resistance and moisture content under different compression stress 


\section{Effect of Organic Matter}

When adding organic matter at $5 \%$ by weight to soil, similar tendencies to the non-addition of organic matter were observed for the relationship between the bulk density and moisture content but with lower bulk density values as shown in Fig. 6. The average overall moisture contents, compared with the non-addition of organic matter, produced bulk densities with a $3.9,3.8$ and $7.7 \%$ reduction for loam, silty clay loam and silt loam, respectively.

\section{Statistical Analysis}

Two-way ANOVA analysis for the test results under uni-axial compression at $200 \mathrm{kPa}$ indicated that there were significant differences in the bulk density (Table 2) and in the penetration resistance (Table 3) among soil types. Loam had the highest average bulk density of $1.485 \mathrm{~g} / \mathrm{cm}^{3}$ whereas silty clay loam had the lowest average bulk density of $1.434 \mathrm{~g} / \mathrm{cm}^{3}$ (Table 4).
The highest average penetration resistance of 775.0 $\mathrm{kPa}$ was recorded in the silt loam and the lowest value of $468.8 \mathrm{kPa}$ in the loam. The moisture content also affected both the bulk density and penetration resistance. The bulk density increased from its lowest value of $1.333 \mathrm{~g} / \mathrm{cm}^{3}$ at $10 \%$ moisture content to $1.611 \mathrm{~g} / \mathrm{cm}^{3}$ at $20 \%$ moisture content (Table 5). On the other hand, the penetration resistance decreased from its highest value of $870.8 \mathrm{kPa}$ at $10 \%$ moisture content to $308.3 \mathrm{kPa}$ at $20 \%$ moisture content. However, the organic matter showed a significant effect only on the bulk density. In the bulk density analysis, the interaction effect between the soil type and the moisture content provided more detail in that all levels of moisture content were significantly different except at 12 and $14 \%$ as well at 16 and $18 \%$ for silt loam. The interaction between the soil type and organic matter showed that the bulk density of each soil with added organic matter was significantly different but without organic matter added, the silt soil and loam soil were not significantly different in bulk density.

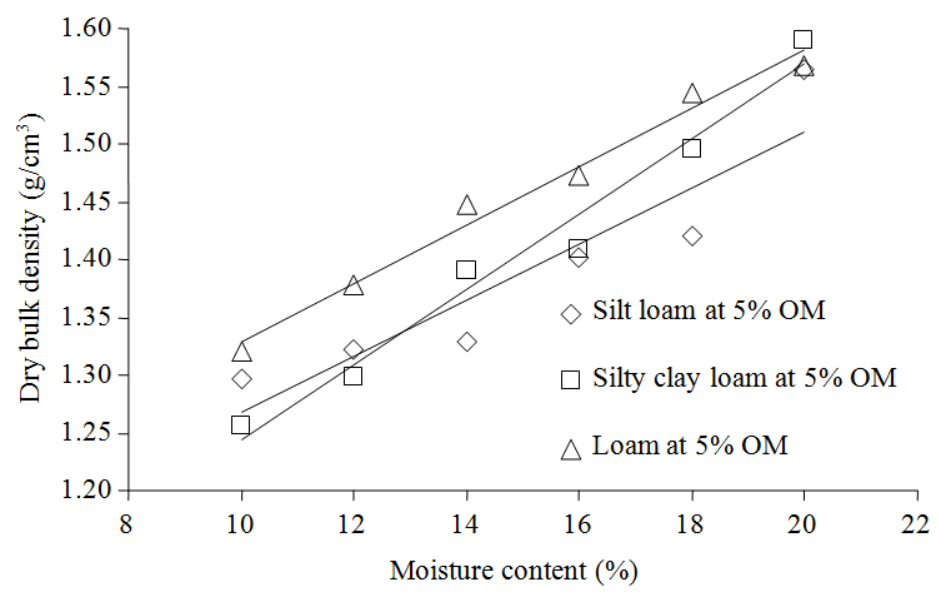

Fig. 6. Bulk density and moisture content for different soils at 5\% OM

Table 2 Statistical analysis result for bulk density

\begin{tabular}{lcrc}
\hline Item & Degrees of freedom & F ratio & p-value \\
\hline SOIL & 2 & 51.191 & 0.000 \\
OM & 1 & 318.647 & 0.000 \\
MC & 5 & 371.336 & 0.000 \\
SOIL * OM & 2 & 20.498 & 0.000 \\
SOIL * MC & 10 & 5.802 & 0.000 \\
OM * MC & 5 & 1.470 & 0.224 \\
SOIL * OM *MC & 10 & 2.824 & 0.011 \\
\hline
\end{tabular}

Table 3. Statistical analysis result for penetration resistance

\begin{tabular}{lcrc}
\hline Item & Degrees of freedom & F ratio & p-value \\
\hline SOIL & 2 & 65.279 & 0.000 \\
OM & 1 & 0.205 & 0.653 \\
MC & 5 & 49.646 & 0.000 \\
SOIL * OM & 2 & 0.676 & 0.515 \\
SOIL * MC & 10 & 4.952 & 0.000 \\
OM * MC & 5 & 1.251 & 0.306 \\
SOIL * OM *MC & 10 & 2.172 & 0.043 \\
\hline
\end{tabular}


Table 4. Average bulk density and cone index for different soil type

\begin{tabular}{lll}
\hline Soil type & Bulk density $\left(\mathrm{g} / \mathrm{cm}^{3}\right)$ & Penetration resistance $(\mathrm{kPa})$ \\
\hline Silty clay loam & $1.434 \mathrm{a}$ & $756.2 \mathrm{~b}$ \\
Silt loam & $1.447 \mathrm{~b}$ & $775.0 \mathrm{~b}$ \\
Loam & $1.485 \mathrm{c}$ & $468.8 \mathrm{a}$ \\
\hline
\end{tabular}

Remark: Figures in the same column with the same lower case letter are not significantly different by Duncan's multiple range test at the $95 \%$ significance level

Table 5. Average bulk density and cone index at different moisture content

\begin{tabular}{lll}
\hline Moisture content $(\% \mathrm{db})$ & Bulk density $\left(\mathrm{g} / \mathrm{cm}^{3}\right)$ & Penetration resistance $(\mathrm{kPa})$ \\
\hline 10 & $1.333 \mathrm{a}$ & $870.8 \mathrm{e}$ \\
12 & $1.375 \mathrm{~b}$ & $845.8 \mathrm{de}$ \\
14 & $1.420 \mathrm{c}$ & $762.5 \mathrm{~d}$ \\
16 & $1.474 \mathrm{~d}$ & $658.3 \mathrm{c}$ \\
18 & $1.517 \mathrm{e}$ & $554.2 \mathrm{~b}$ \\
20 & $1.611 \mathrm{f}$ & $308.3 \mathrm{a}$ \\
\hline
\end{tabular}

Remark: Figures in the same column with the same lower case letter are not significantly different by Duncan's multiple range test at the $95 \%$ significance level

\section{Discussion}

The modified Proctor test resulted in a higher maximum bulk density in the soil. This may have been due to the fact that the impact force generated higher energy into the soil when compared to the static compression in the oedometer test. Hakansson (1990) found that a Proctor test resulted in between 7 and 17\% higher bulk densities than an oedometer test. Soil samples used by Hakansson (1990) were categorized from loamy soil to clay with the silt content varying from 3 to $40 \%$. The bulk density can be used to determine if a soil is too compact to allow root penetration. Bulk densities that limit plant growth vary for soils of different textural classes. Arshad et al. (1996) reported that the ideal bulk density for silt loam is less than $1.40 \mathrm{~g} / \mathrm{cm}^{3}$, whereas bulk densities affecting root growth started from $1.60 \mathrm{~g} / \mathrm{cm}^{3}$ and roots were restricted when the bulk density was more than $1.75 \mathrm{~g} / \mathrm{cm}^{3}$. The bulk density recorded using the oedometer test for the silt loam in this study confirmed its relevance as the bulk density was in the range affecting root growth whereas the reading using the Proctor test was much higher even than the bulk density level that restricts root growth, based on data from Arshad et al. (1996).

Aragon et al. (2000) studied the maximum compatibility of Argentinean soils using the Proctor test. They found that the maximum bulk density was highly correlated with the organic carbon content and the silt content. The increased silt content reduced the soil compactability at the same organic matter content. However, in our study, the bulk density resulting from compacting the soil under uni-axial compression did not show any relationship with the silt content of the soils. The highest bulk density was found in the loam soil with the least silt content of $40.72 \%$ whereas the second highest was in the silt loam with the highest silt content of $55.44 \%$ and the lowest bulk density was in the silty clay loam with a silt content of $50.72 \%$. Adding organic matter to soils resulted in decreased bulk density and this agreed with other research work by Aragon et al. (2000; Arvidsson, 1998).

Hummel et al. (2004) reported the clay content of the soil as a significant variable in predictions of penetration resistance. The clay content was a statistically significant variable in the prediction of the cone index across all soils, irrespective of the source of soil moisture values. Kumar et al. (2012) reported that values of the cone index decreased with increased clay fraction; furthermore, they increased with increased sand and silt fractions of the soil. In the current study, the penetration resistance seemed to increase with the increased silt content with the increasing order of loam $(40.72 \%$ silt $)$, silty clay loam (50.72\% silt) and silt loam (55.44\% silt)).

No significant effect of organic matter on the penetration resistance was found in the current study and this was consistent with the results reported by Mosaddeghi et al. (2000). They used a two-wheel drive Universal tractor with static weights on the front and rear axles of 1,197 and 2,193 $\mathrm{kg}$ and inflation pressure in the front and rear tyres at 228 and $105 \mathrm{kPa}$ to compact the soil. It was observed that in one pass of the tractor, there was no significant difference between manure treatments; however, with two passes of the tractor, more farmyard manure gave less resistance against additional penetration.

According to Arshad et al. (1996), ideal bulk densities for plant growth, bulk densities that affect root growth and bulk densities that restrict root growth were $<1.40,1.63$ and $>1.80 \mathrm{~g} / \mathrm{cm}^{3}$, for loam soil, respectively, $<1.40,1.60$ and $>1.75 \mathrm{~g} / \mathrm{cm}^{3}$ for silt loam, respectively and $<1.40,1.55$ and $>1.65 \mathrm{~g} / \mathrm{cm}^{3}$ for silty clay loam, respectively. From the results of the bulk density research in the current work, it is recommended that machines with $200 \mathrm{kPa}$ tire contact pressure should only 
work in fields at a moisture content that does not exceed $20.27,18.74$ and $17.88 \%$ for loam, silt loam and silty clay loam, respectively, in order to avoid effects on root growth. Adding organic matter helped soils to resist greater machine loads, resulting in higher critical levels of moisture content of $21.97,23.65$ and $19.43 \%$ for loam, silt loam and silty clay loam, respectively.

\section{Conclusion}

Compacting silt loam soil using the modified Proctor test resulted in a higher bulk density than from using the oedometer test at a vertical, normal stress of $200 \mathrm{kPa}$. The maximum bulk density using the oedometer test was within the range that affected root growth whereas the bulk density measured using the Proctor test was much higher and even greater than the bulk density that restricted root growth based on data from Arshad et al. (1996). Statistical analysis of the test results under uniaxial compression at $200 \mathrm{kPa}$ indicated that there were significant differences among soil types in the bulk density and penetration resistance. The moisture content affected both the bulk density and penetration resistance. However, organic matter showed a significant effect only on bulk density. The bulk density increased with increased moisture content. Among the three soils, loam showed the highest value of bulk density followed by silt loam and silty clay loam. The difference in bulk density among these three soils decreased as the moisture content increased. The penetration resistance seemed to increase with increased silt content in the order of loam ( $40.72 \%$ silt $)$, silty clay loam $(50.72 \%$ silt $)$ and silt loam (55.44\% silt). Silty clay loam and silt loam showed greater decreased values of penetration resistance with increasing moisture content; resulting in nearly similar values at a moisture content of $20 \%$. The bulk density and penetration resistance were higher under higher uni-axial compression and their differences became smaller as the moisture content increased. Adding organic matter at $5 \%$ by weight to soil resulted in lower bulk densities of soil based on the oedometer test. This study recommends that machines with $200 \mathrm{kPa}$ of tire contact pressure should only work in fields where the moisture content is not more than 20.27, 18.74 and $17.88 \%$ for loam, silt loam and silty clay loam, respectively, in order to avoid effects on root growth. Adding organic matter helped soils to resist a greater machine load, resulting in a higher critical level of moisture content of $21.97,23.65$ and $19.43 \%$ for loam, silt loam and silty clay loam, respectively.

\section{Acknowledgement}

The authors gratefully acknowledge the Kasetsart University Research and Development Institute
(KURDI) for financial support under the research project entitled "Study on alleviation of silt compaction in sugarcane field".

\section{Author's Contributions}

Prathuang Usaborisut: Designed and planned the current research work and analyzed and interpreted the results.

Jettapol Ampanmanee: Conducted the experiments and collected the data.

\section{Ethics}

This article is original and contains unpublished material. The corresponding author confirms that all of the other authors have read and approved the manuscript and no ethical issues involved.

\section{References}

Al-Gaadi, K.A., 2012. Employing electromagnetic induction technique for the assessment of soil compaction. Am. J. Agric. Biol. Sci., 7: 425-434. DOI: 10.3844/ajabssp.2012.425.434

Al-Gaadi, K.A., 2013. Assessment of soil compaction under center pivot irrigation systems and its effect on crop performance. Am. J. Agric. Biol. Sci., 8: 54-66. DOI: 10.3844/ajabssp.2013.54.66

Aragon, A., M.G. Garcia, R.R. Filgueira and Y.A. Pachepsky, 2000. Maximum compactibility of Argentine soils from the Proctor test: The relationship with organic carbon and water content. Soil Tillage Res., 56: 197-204. DOI: 10.1016/S0167-1987(00)00144-6

Arshad, M.A., B. Lowery and B. Grossman, 1996. Physical Tests for Monitoring Soil Quality. In: Methods for Assessing Soil Quality, Doran, J.W. and A.J. Jones (Eds.), SSSA, Madison, WI., pp: 123-141.

ASTM D1557-12, 2012. Standard-test methods for laboratory compaction characteristics of soil using modified effort $\left(56,000 \mathrm{ft}-\mathrm{lbf} / \mathrm{ft}^{3}(2,700 \mathrm{kN}-\right.$ $\left.\left.\mathrm{m} / \mathrm{m}^{3}\right)\right)$. ASTM International, West Conshohocken.

ASTM D2974-14, 2014. Standard test methods for moisture, ash and organic matter of peat and other organic soils. ASTM International, West Conshohocken, PA.

Arvidsson, J., 1998. Influence of soil texture and organic matter content on bulk density, air content, compression index and crop yield in field and laboratory compression experiments. Soil Tillage Res., 49: 159-170 DOI: 10.1016/S0167-1987(98)00164-0 
Busscher, W.J., P.J. Bauer, C.R. Camp and R.E. Sojka, 1997. Correction of cone index for soil water content differences in a coastal plain soil. Soil Till. Res., 43: 205-217.

DOI: $10.1016 / \mathrm{S} 0167-1987(97) 00015-9$

CAI, 2014. Agricultural statistics of Thailand, Crop Year 2014. Centre for Agricultural Information, Office of Agricultural Economics, Ministry of Agriculture and Cooperatives, Bangkok, Thailand.

Carter, M.R., 1990. Relative measures of soil bulk density to characterize compaction in tillage studies on fine sandy loams. Can. J. Soil Sci., 70: 425-433. DOI: $10.4141 /$ cjss90-042

Da Silva, A.P., B.D. Kay and E. Perfect, 1997. Management versus inherent soil properties effects on bulk density and relative compaction. Soil Tillage Res., 44: 81-93. DOI: $10.1016 / \mathrm{S} 0167-1987(97) 00044-5$

Hakansson, I., 1990. A method for characterizing the state of compactness of the plough layer. Soil Till. Res., 16: 105-120. DOI: $10.1016 / 0167-1987(90) 90024-8$

Hakansson, I. and J. Lipiec, 2000. A review of the usefulness of relative bulk density values in studies of soil structure and compaction. Soil Tillage Res., 53: 71-85. DOI: 10.1016/S0167-1987(99)00095-1

Hummel, J.W., I.S. Ahmad, S.C. Newman, K.A. Sudduth and S.T. Drummond, 2004. Simultaneous soil moisture and cone index measurement. Trans. ASAE, 47: 607-618. DOI: 10.13031/2013.16090
Kumar, A., Y. Chen, A. Sadek and S. Rahman, 2012. Soil cone index in relation to soil texture, moisture content and bulk density for no-tillage and conventional tillage. Agric. Eng. Int., 14: 26-37.

Mosaddeghi, M., M. Hajabbasi, A. Hemmat and M. Afyuni, 2000. Soil Compactibility as affected by soil moisture content and farmyard manure in central Iran. Soil Tillage Res., 55: 87-97. DOI: 10.1016/S0167-1987(00)00102-1

Usaborisut, P. and T. Niyamapa, 2010. Effects of machine-induced soil compaction on growth and yield of sugarcane. Am. J. Agric. Biol. Sci., 5: 269-273. DOI: 10.3844/ajabssp.2010.269.273

Usaborisut, P. and W. Sukcharoenvipharat, 2011. Soil compaction in sugarcane fields induced by mechanization. Am. J. Agric. Biol. Sci., 6: 418-422. DOI: 10.3844/ajabssp.2011.418.422

Yahya, Z., A. Husin, J. Talib, J. Othman and O.H. Ahmed et al., 2009. Machinery compaction effects on physical properties of Bernam series in an oil palm plantation. Am. J. Applied Sci., 6: 2006-2009. DOI: 10.3844/ajassp.2009.2006.2009

Yahya, Z., A. Husin, J. Talib, J. Othman and O.H. Ahmed et al., 2010. Oil Palm (Elaeis guineensis) roots response to mechanization in bernam series soil. Am. J. Applied Sci., 7: 343-348.

DOI: 10.3844 /ajassp.2010.343.348 